\title{
SOYBEAN GROWTH AND YIELD WITH APPLICATION OF PHOSPHATE FERTILIZER AND ORGANIC MATTER
}

\author{
Lely Wahidah Nasution ${ }^{1 *}$, Chairani Hanum², Hamidah Hanum ${ }^{2}$ \\ ${ }^{1}$ Post graduate of Agrotechnology, Agriculture Faculty, University of North Sumatra, Medan, Indonesia \\ ${ }^{2}$ Agrotechnology Department, Agriculture Faculty, University of North Sumatra, Medan, Indonesia \\ *Corresponding Author: lelynst22@gmail.com
}

\begin{abstract}
Soybean is useful for tofu, tempe, soy sauce and soy milk. The effective use of fertilizer and organic application can increase soybean productivity. The objective of this research was to study the growth and yield of various soybean varieties on application of phospate fertilizer and organic matter. This research was conducted in North Binjai and Research and Technology Laboratory Agriculture Faculty Universitas Sumatera Utara, Medan on May-September 2016. The method used Randomized Block Design with 3 factors. The first factor is soybean varieties consisting of: (Argomulyo, Dering, Dena, Kaba, Gema, Grobogan and Wilis), fertilization of phosphate (control and $150 \mathrm{~kg} / \mathrm{ha}$ ) and organic material application (control, Blotong 10 ton/ha and POEFBC/Palm Oil Empty Fruit Bunches Compost 10 ton / Ha). The results of this research showed that the seven varieties of soybean had characteristic differences on shoot dry weight, age of flowering, age of harvest, phospate uptake and dry weight of 100 seed. The longest flowering and harvesting age is obtained in Wilis, while the shortest age is Grobogan. The highest uptake of $P$ in Argomulyo with treatment without organic matter and phospate fertilizer. Kaba variety with blotong treatment has the highest dry seed weight.
\end{abstract}

Keywords : Organic Matter, Phosphate Fertilizer, Soybean Varieties

\section{INTRODUCTION}

Soybean is a commodity that has commercial value and good prospect to be developed because it is very needed by the people of Indonesia as a source of vegetable protein. The standard protein needed by the Indonesian population per day is $46 \mathrm{~g}$ protein per person and can only be fulfilled about 37-39 $\mathrm{g}$ (Zahrah, 2011).

The period January to August 2015 recorded imports of soybeans reached 1,525,748 tons with a value of US \$ $719,807,624$. This amount decreased $2 \%$ in the same period in 2014 which reached $1,564,163$ with a value of US \$ 947,245,608 (Central Bureau of Statistics, 2015).

One alternative to overcome obstacles is through the arrangement of planting time, and the management of $\mathrm{P}$ nutrients and the addition of soil organic matter. Each variety has unequal genetic characteristics, it can be seen from the appearance and character of each of these varieties. Thus it can be stated that the growth and production of soybeans will be influenced by varieties, soil and plant management, and other environmental conditions (Zahrah, 2011).

Phosphorus nutrients are the key to plant life, because they are involved in all metabolic processes of plants and encourage root growth, flower formation, fruiting and seeding (Gunarto et al., 1998). Compost has several beneficial properties such as: improving soil structure, increasing the water holding capacity of the soil, enhancing the binding capacity of soil to nutrients, helping the process of weathering mineral materials and providing food supplies for microbes (Indriani, 2007). The combination of soybean varieties with P nutrient management as well as the addition of organic matter will help sustain the productivity of soybeans.

The objective of this study was to evaluate the differences in growth and production of various soybean varieties, compare the effects between types of $\mathrm{P}$ fertilizers, compare the effect among the types of organic materials on, compare the effect of organic matter combined with P fertilizer on growth and production and to know the effect of interaction between varieties, organic and P fertilizers to the growth and production of soybeans.

\section{MATERIALS AND METHOD}

This research was conducted in North Binjai and Research and Technology Laboratory Agriculture Faculty Universitas Sumatera Utara, Medan on May-September 2016. This research used Randomized Block Design with 3 factors. The first factor is soybean varieties consisting of: (Argomulyo, Dering, Dena, Kaba, Gema, Grobogan and 
Wilis), fertilization of phosphate (control and $150 \mathrm{~kg} / \mathrm{ha}$ ) and organic material application (control, Blotong 10 ton/ha and Palm Oil Empty Fruit Bunches Compost 10 ton / Ha).

The application of organic material (Palm Oil Empty Fruit Bunches Compost and blotong) made by mixing into the planting medium already in tugal in accordance with the level of treatment and applied in the afternoon (240 $\mathrm{g} /$ plant). Fertilization $\mathrm{P}$ is done by calculating the fertilizer requirement in accordance with the treatment level, applied to land already in tugal in the afternoon $(2.4 \mathrm{~g} /$ plant $)$. Application of fertilizers ( $\mathrm{N} 0.2 \mathrm{~g} / \mathrm{plant}$ and $\mathrm{K} 0.8 \mathrm{~g} /$ plant) as initial stater/fertilizer was done in accordance with the recommended dosage. Watering is only done from the beginning of planting to 2 WAP (adjusted to the field conditions). Number of watering volume $51.6 \mathrm{ml} / \mathrm{plant}$. The observed variables were root dry weight $(\mathrm{g})$, flowering age (day), harvest age (day), nutrient uptake $\mathrm{P}$ (mg / plant) and weight of 100 dry seeds (g). The data were analyzed statistically using F-test and then following by Duncan Multiple Range Test at $5 \%$ level.

\section{RESULTS AND DISCUSS}

\subsection{Dry root weight $(g)$}

The result of $\mathrm{F}$ test showed that the treatment of varieties, phosphates, organic matter, the interaction of varieties with phosphate, varieties with organic matter, organic matter with phosphate, varieties, phosphate with organic matter showed no significant difference to root dry weight parameters. Varieties with the highest average dry root weight were obtained in Argomulyo (V1), while the lowest varieties of Gema (V5) (Table 1). Although statistically not significantly different but the granting of organic material blotong produce the highest root dry weight. Without the application of $\mathrm{P}$ fertilizer it produces dry weights of roots higher than the fertilizer application. The addition of organic material to each variety then given $\mathrm{P}$ fertilizer generally decreases root dry weight (Table 1).

Table 1. Dry Weed Root Several Varieties of Soy With Treatment Fertilizer $P$ and Addition of Organic Material

\begin{tabular}{|c|c|c|c|}
\hline \multirow[b]{2}{*}{ Treatment } & \multicolumn{2}{|c|}{ Fertilizer } & \multirow[b]{2}{*}{ Average } \\
\hline & $\begin{array}{c}\text { P0 } \\
\text { Control }\end{array}$ & $\begin{array}{c}\mathrm{P} 1 \\
\text { Fertilizer } \mathrm{P}\end{array}$ & \\
\hline \multicolumn{4}{|l|}{ Variety } \\
\hline V1(Argomulyo) & 1.15 & 0.91 & 1.03 \\
\hline V2(Dering) & 0.91 & 0.69 & 0.80 \\
\hline V3(Dena) & 0.90 & 0.73 & 0.81 \\
\hline V4(Kaba) & 0.78 & 0.78 & 0.78 \\
\hline V5(Gema) & 0.56 & 0.57 & 0.57 \\
\hline V6(Grobogan) & 0.85 & 0.80 & 0.82 \\
\hline V7(Wilis) & 0.59 & 0.72 & 0.65 \\
\hline \multicolumn{4}{|l|}{ Organic Matter } \\
\hline B0(Control) & 0.83 & 0.71 & 0.77 \\
\hline B1(Blotong) & 0.86 & 0.76 & 0.81 \\
\hline B2(POEFBC) & 0.77 & 0.75 & 0.76 \\
\hline \multicolumn{4}{|l|}{ Interaction $\mathrm{VxPxB}$} \\
\hline V1B0(Argomulyo;Control) & 1.34 & 0.91 & 1.12 \\
\hline V1B1(Argomulyo;Blotong) & 1.16 & 0.93 & 1.04 \\
\hline V1B2(Argomulyo; POEFBC) & 0.96 & 0.89 & 0.92 \\
\hline V2B0(Dering;Control) & 0.69 & 0.70 & 0.70 \\
\hline V2B1(Dering;Blotong) & 0.96 & 0.89 & 0.93 \\
\hline V2B2(Dering; POEFBC) & 1.08 & 0.47 & 0.78 \\
\hline V3B0(Dena;Control) & 0.72 & 0.54 & 0.63 \\
\hline V3B1(Dena;Blotong) & 0.90 & 0.59 & 0.75 \\
\hline V3B2(Dena; POEFBC) & 1.07 & 1.05 & 1.06 \\
\hline V4B0(Kaba;Control) & 0.77 & 0.57 & 0.67 \\
\hline V4B1(Kaba;Blotong) & 0.78 & 1.09 & 0.93 \\
\hline
\end{tabular}




\begin{tabular}{llll} 
V4B2(Kaba; POEFBC) & 0.79 & 0.68 & 0.73 \\
V5B0(Gema;Control) & 0.54 & 0.63 & 0.59 \\
V5B1(Gema:Blotong) & 0.52 & 0.35 & 0.44 \\
V5B2(Gema: POEFBC) & 0.63 & 0.74 & 0.68 \\
V6B0(Grobogan;Control) & 1.04 & 0.85 & 0.94 \\
V6B1(Grobogan;Blotong) & 0.99 & 0.89 & 0.94 \\
V6B2(Grobogan: POEFBC) & 0.51 & 0.66 & 0.59 \\
V7B0(Wilis;Control) & 0.73 & 0.82 & 0.77 \\
V7B1(Wilis;Blotong) & 0.70 & 0.59 & 0.64 \\
V7B2(Wilis; POEFBC) & 0.34 & 0.75 & 0.55 \\
\hline \multicolumn{1}{c}{ Average } & 0.82 & 0.74 & 0.78 \\
\hline
\end{tabular}

Note: The numbers followed by the same letter on the same row or column is not different significant according to Duncan Multiple Range Test at 5\% level.

The treatment of P fertilizer, giving organic matter to soybean varieties did not give a significant effect on root dry weight (Table 1). The unpredictable effect of $\mathrm{P}$ administration is allegedly caused by the sour soil conditions. Result of soil chemical fertility analysis obtained that the $\mathrm{pH}$ of soil used is 4.2 . Low soil $\mathrm{pH}$ is resulting in low nutrient availability. Although the soil is given $\mathrm{P}$ fertilizer but the fertilizer is not available to the plant. The ability of plants to pick up $\mathrm{P}$ is also influenced by the ability of root rhizosphere, plant species, nutrient status in plants, and soil $\mathrm{pH}$ conditions. The optimum $\mathrm{pH}$ for taking $\mathrm{P}$ is 4.5-5 (Raghothama, 1999). The low soil $\mathrm{pH}$ conditions in this study caused the plant to inadequate $\mathrm{P}$. This result caused the application of $\mathrm{P}$ fertilizer not to affect root dry weight.

\subsection{Flowering Age (days)}

The result of F-test showed that the treatment of varieties, interaction of varieties with phosphate, varieties with organic matter, varieties, phosphate, with organic matter had significant effect on flowering age while other treatments such as phosphate, organic matter and organic matter interaction with phosphate showed no significant difference against flowering age parameters.

The average flowering age for each treatment can be seen in Table 2. In Table 2 the varieties with the longest flowering age were obtained on the Wilis (V7) varieties, while the shortest fledged time was obtained in Grobogan (V6) varieties. For the interaction of varieties with organic fertilizers treated with phosphate, the longest flowering age was obtained in the treatment of Wilis varieties without organic matter (V7B0), while the shortest age was obtained in the treatment of Grobogan varieties with blotong (V6B1). The results of this study indicate the association of plant age with flowering time, for example Grobogan is a varieties with age maturity, has a shorter flowering life, unlike Wilis (V7), with characteristics of age.

The results in Table 2 show that each variety responds differently than that of phosphorous fertilizer. There are 6 varieties V1 (Argomulyo), V2 (Vermin), V3 (Dena-1) V5 (Gema), V6 (Grobogan) and V7 (Wilis) not response to fertilization, as well as on varieties V4 (Kaba). Grobogan varieties flowering age faster than the varieties of Wilis. The out-of-pod age of Grobogan varieties is faster than that of the Wilis variety. This shows a significant difference in genetic factors between the two varieties of plants. Genetic factors are the innate traits of each variety. It appears that in this study Grobogan varieties have a better generative advantage than the Wilis varieties in terms of age of interest, the flowering of soybean plants is strongly influenced by varieties, length of day or duration of irradiation and temperature (Cahyono, 2007). The main factor of interest is determined by the genetic properties of a variety used (Darjanto et al., 1987).

At high temperatures and low humidity, the amount of sunlight received more leaves, so that will stimulate the formation of flowers. The giving of organic matter was not significantly different from the age parameter of flowering but without the giving of organic matter (control) became the lowest flowering age. Soybean plants flower faster without the application of phosphate fertilizer due to plant stress caused by lack of P (early stage), mechanism to avoid plants against stress is done by accelerating the phase of his life so that when the stress is heavier, the plant has completed one life cycle. The tolerant mechanism is carried out by involving biochemically and metabolically controlled genes. Plants that have genes for tolerance of abiotic stress will be able to keep growing in environments with environmental stress conditions. While the fertilizer given phosphate base substances form ATP with sufficient $\mathrm{P}$ energy able to complete its life cycle in accordance with the description. These phosphorus elements can encourage root growth, flower formation, fruiting and seeding. Phosphorus is a constituent component of several 
enzymes, proteins, ATP, RNA, and DNA. ATP is important for energy transfer processes, whereas RNA and DNA determine the genetic properties of plants (Adisarwanto, 2008).

Table 2. Age Flowering Soybean Varieties With Fertilizer Treatment $P$ and Addition of Organic Material

\begin{tabular}{|c|c|c|c|}
\hline \multirow[b]{2}{*}{ Treatment } & \multicolumn{2}{|c|}{ Fertilizer } & \multirow[b]{2}{*}{ Average } \\
\hline & $\begin{array}{c}\text { P0 } \\
\text { Control }\end{array}$ & $\begin{array}{c}\mathrm{P} 1 \\
\text { Fertilizer } \mathrm{P}\end{array}$ & \\
\hline Variety & \multicolumn{2}{|c|}{.........day......... } & \\
\hline V1(Argomulyo) & $41.44 \mathrm{e}$ & $41.33 \mathrm{e}$ & $41.39 \mathrm{~d}$ \\
\hline V2(Dering) & $46.22 \mathrm{~cd}$ & $46.33 c$ & $46.28 b$ \\
\hline V3(Dena) & $47.00 \mathrm{~b}$ & $45.67 \mathrm{~cd}$ & $46.33 b$ \\
\hline V4(Kaba) & $45.56 \mathrm{~d}$ & $46.11 \mathrm{~cd}$ & $45.83 c$ \\
\hline V5(Gema) & $38.89 f$ & $39.22 \mathrm{f}$ & $39.06 \mathrm{e}$ \\
\hline V6(Grobogan) & $36.11 \mathrm{~g}$ & $35.33 \mathrm{~h}$ & $35.72 f$ \\
\hline V7(Wilis) & $51.22 \mathrm{a}$ & $51.67 \mathrm{a}$ & $51.44 \mathrm{a}$ \\
\hline \multicolumn{4}{|l|}{ Organic Matter } \\
\hline B0(Control) & 43.67 & 43.90 & 43.79 \\
\hline B1(Blotong) & 43.76 & 43.48 & 43.62 \\
\hline B2(POEFBC) & 43.90 & 43.62 & 43.76 \\
\hline \multicolumn{4}{|l|}{ Interaction $\mathrm{VxPxB}$} \\
\hline V1B0(Argomulyo;Control) & $40.67 \mathrm{~h}$ & $42.00 \mathrm{~g}$ & $41.33 \mathrm{e}$ \\
\hline V1B1(Argomulyo;Blotong) & $41.67 \mathrm{~g}$ & $41.00 \mathrm{~g}$ & $41.33 \mathrm{e}$ \\
\hline V1B2(Argomulyo; POEFBC) & $42.00 \mathrm{~g}$ & $41.00 \mathrm{~g}$ & $41.50 \mathrm{e}$ \\
\hline V2B0(Dering;Control) & $46.00 \mathrm{ef}$ & $46.33 \mathrm{~d}-\mathrm{f}$ & $46.17 \mathrm{~cd}$ \\
\hline V2B1(Dering;Blotong) & $46.67 \mathrm{de}$ & $46.33 \mathrm{~d}-\mathrm{f}$ & $46.50 \mathrm{~cd}$ \\
\hline V2B2(Dering; POEFBC) & $46.00 \mathrm{ef}$ & $46.33 \mathrm{~d}-\mathrm{f}$ & $46.17 \mathrm{~cd}$ \\
\hline V3B0(Dena;Control) & $47.33 \mathrm{~d}$ & $46.33 \mathrm{~d}-\mathrm{f}$ & $46.83 c$ \\
\hline V3B1(Dena;Blotong) & $47.33 d$ & $45.33 f$ & $46.33 \mathrm{~cd}$ \\
\hline V3B2(Dena; POEFBC) & $46.33 \mathrm{~d}-\mathrm{f}$ & $45.33 \mathrm{f}$ & $45.83 \mathrm{~d}$ \\
\hline V4B0(Kaba;Control) & $45.67 \mathrm{ef}$ & $46.00 \mathrm{ef}$ & $45.83 d$ \\
\hline V4B1(Kaba;Blotong) & $45.33 \mathrm{f}$ & $46.33 \mathrm{~d}-\mathrm{f}$ & $45.83 \mathrm{~d}$ \\
\hline V4B2(Kaba; POEFBC) & $45.67 \mathrm{ef}$ & $46.00 \mathrm{ef}$ & $45.83 d$ \\
\hline V5B0(Gema;Control) & $38.00 \mathrm{kl}$ & $39.00 \mathrm{i}-\mathrm{k}$ & $38.50 \mathrm{~g}$ \\
\hline V5B1(Gema:Blotong) & $39.00 \mathrm{i}-\mathrm{k}$ & $38.67 \mathrm{jk}$ & $38.83 \mathrm{~g}$ \\
\hline V5B2(Gema: POEFBC) & $39.67 \mathrm{~h}-\mathrm{j}$ & 40.00hi & $39.83 f$ \\
\hline V6B0(Grobogan;Control) & $35.00 \mathrm{n}$ & $36.00 \mathrm{mn}$ & $35.50 \mathrm{~h}$ \\
\hline V6B1(Grobogan;Blotong) & $36.33 \mathrm{~m}$ & $35.00 \mathrm{n}$ & $35.67 \mathrm{~h}$ \\
\hline V6B2(Grobogan: POEFBC) & $37.001 \mathrm{~m}$ & $35.00 \mathrm{n}$ & $36.00 \mathrm{~h}$ \\
\hline V7B0(Wilis;Control) & $53.00 \mathrm{a}$ & $51.67 \mathrm{~b}$ & $52.33 \mathrm{a}$ \\
\hline V7B1(Wilis;Blotong) & $50.00 \mathrm{c}$ & $51.67 \mathrm{~b}$ & $50.83 b$ \\
\hline V7B2(Wilis; POEFBC) & $50.67 \mathrm{bc}$ & $51.67 \mathrm{~b}$ & $51.17 \mathrm{~b}$ \\
\hline Average & 43.78 & 43.67 & 43.72 \\
\hline
\end{tabular}

Note: The numbers followed by the same letter on the same row or column is not different significant according to Duncan Multiple Range Test at 5\% level

\subsection{Harvest Age (days)}

F test results show that the treatment of varieties; organic matter; interaction of organic matter with phosphate; varieties with organic matter; varieties, phosphates, with organic matter; have significant effect on flowering age 
whereas other treatments such as phosphate, phosphate interaction with varieties show unreal difference to harvest age parameter.

The results in Table 3 show that each variety has a different harvesting age. Varieties with the longest harvest age average are Wilis (V7), while the shortest harvest age is obtained on Gema (V5) and Grobogan (V6) varieties. The giving of organic matter had a significant effect on the age of soybean harvest. The longest harvest age was obtained on soil given organic matter without $\mathrm{P}$ fertilizer, while the shortest life was obtained in the treatment without organic matter and $P$ fertilizer (Table 3). The interaction of varieties, organic matter, and $P$ fertilizer had significant effect on the age of soybean harvest. The longest harvest time was obtained in combination of V7B2P1 treatment (Wilis varieties with palm oil empty fruit bunches compost organic fertilizer plus P fertilizer). The shortest harvest age is obtained on V6B0P0 (combination of Grobogan varieties, without organic matter, without the addition of $\mathrm{P}$ fertilizer).

The results in Table 3 show that each variety responds differently than that of phosphorus fertilizer. There are 6 varieties V1 (Argomulyo), V3 (Dena-1), V4 (Kaba), V5 (Gema), V6 (Grobogan) and V7 (Wilis) not response to fertilization, as opposed to varieties V2 (Dering), the response fertilization. The giving of organic material did not differ significantly to harvest age parameter but with palm oil empty fruit bunches compost giving longer harvest time. The $\mathrm{C} / \mathrm{N}$ ratio of palm oil empty fruit bunches compost is 15 i.e. close to the $\mathrm{C} / \mathrm{N}$ ratio of soil, so that nutrients become available to the plant. The role of organic matter to the biological properties of the soil is to increase microorganism activity that plays a role in nitrogen fixation and certain nutrient transfer such as $\mathrm{N}, \mathrm{P}, \mathrm{K}$, and $\mathrm{S}$. The role of organic matter to soil chemical properties is to increase cation exchange capacity so that it can affect nutrient uptake by plants (Leovici, 2012). The seventh harvest varieties tested in this study differed. Variety Wilis tended to require the longest harvest period of 90 days, and the Grobogan varieties tended to be faster at \pm 76 days (Suhartina, 2005).

\subsection{Nutrient Uptake $P$ (mg/plant)}

The result of $\mathrm{F}$ test showed that the treatment of varieties, phosphates, organic matter, interaction of varieties with phosphate, the interaction of organic matter with phosphate, the interaction of varieties with organic matter, the interaction of varieties, phosphate with organic matter had significant effect on nutrient uptake of plant P. The nutrient uptake of $\mathrm{P}$ plants for each treatment can be seen in Table 4. The results in Table 4 shows the varieties with the highest P nutrient uptake of V6 (Grobogan), while the lowest is V7 (Wilis). Interaction of varieties with the highest $\mathrm{P}$ fertilizer V6P1 (Grobogan with the addition of $\mathrm{P}$ fertilizer) and the lowest on V7P1 (Wilis with the addition of $\mathrm{P}$ fertilizer). The organic materials with the highest $\mathrm{P}$ nutrient uptake were obtained at B1 (Blotong), while the lowest was B0 (without the treatment of organic matter). Interaction of organic material with the highest $\mathrm{P}$ fertilizer on organic material B1P0 (Blotong without addition of P fertilizer) and the lowest B0P0 (without addition of organic material and without addition of $\mathrm{P}$ fertilizer) (Table 4).

Without the application of P fertilizer it produces the highest nutrient uptake of P. On soils given the highest organic material and variety V7B2 (Ringing with the addition of palm oil empty fruit bunches compost organic material) and the lowest V5B2 (Gema with the addition of palm oil empty fruit bunches compost organic material). Interaction of varieties with organic fertilizer given P, highest V2B2P0 (Dried varieties with palm oil empty fruit bunches compost organic fertilizer without P), lowest V4B0P1 (Kaba without organic matter with P fertilizer).

Table 3. Harvest Age Several Soybean Varieties With Fertilizer P Treatment and Addition of Organic Material

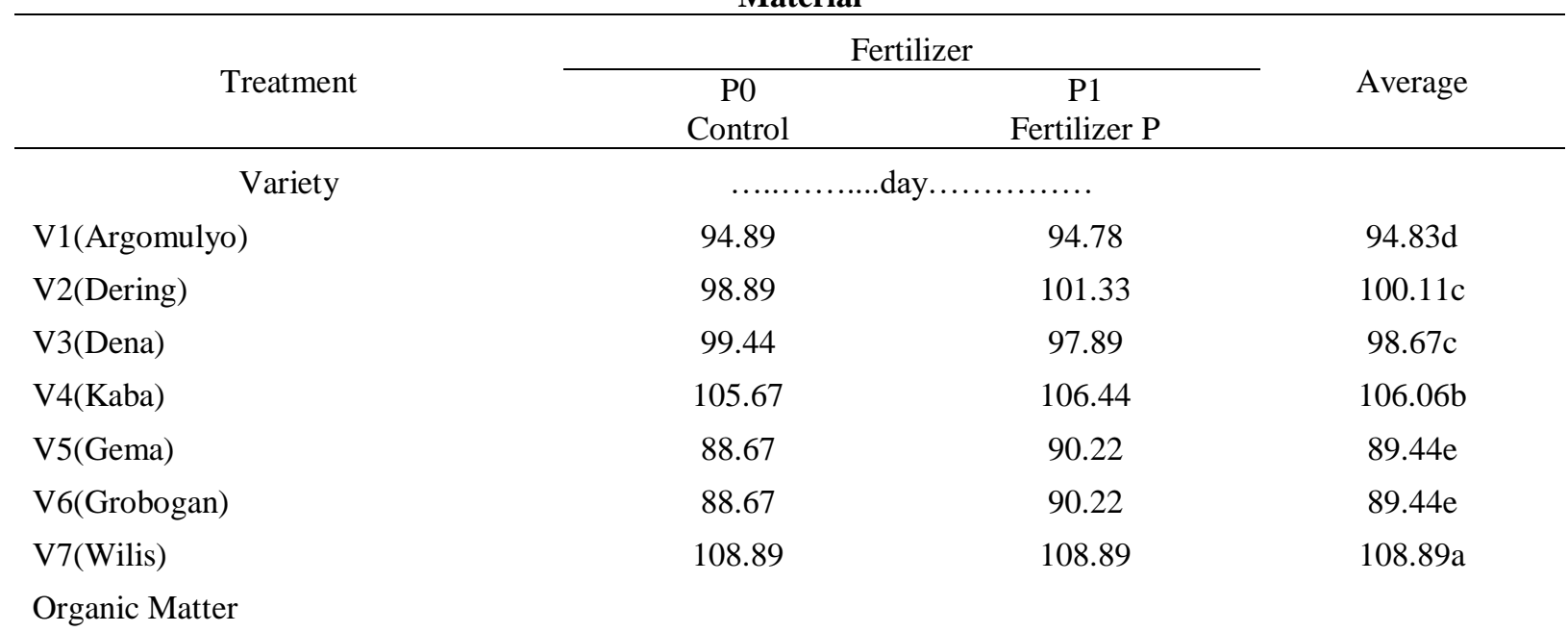




\begin{tabular}{|c|c|c|c|}
\hline B0(Control) & $94.38 \mathrm{c}$ & $98.67 \mathrm{ab}$ & $96.52 b$ \\
\hline B1(Blotong) & $98.57 \mathrm{ab}$ & $99.00 \mathrm{ab}$ & $98.79 \mathrm{a}$ \\
\hline B2(POEFBC) & $106.67 \mathrm{a}$ & $97.95 b$ & $99.31 \mathrm{a}$ \\
\hline \multicolumn{4}{|l|}{ Interaction $\mathrm{VxPxB}$} \\
\hline V1B0(Argomulyo;Control) & $94.00 \mathrm{i}-1$ & $94.67 \mathrm{i}-1$ & $94.33 \mathrm{~g}-\mathrm{i}$ \\
\hline V1B1(Argomulyo;Blotong) & $96.00 \mathrm{~h}-\mathrm{k}$ & $95.00 \mathrm{i}-1$ & $95.50 f-h$ \\
\hline V1B2(Argomulyo; POEFBC) & $94.67 \mathrm{i}-1$ & $94.67 \mathrm{i}-1$ & $94.67 \mathrm{gh}$ \\
\hline V2B0(Dering;Control) & $98.67 f-j$ & $100.00 \mathrm{e}-\mathrm{j}$ & $99.33 d-f$ \\
\hline V2B1(Dering;Blotong) & $98.00 \mathrm{~g}-\mathrm{j}$ & $102.00 \mathrm{~d}-\mathrm{h}$ & $100.00 \mathrm{~d}-\mathrm{f}$ \\
\hline V2B2(Dering; POEFBC) & $100.00 \mathrm{e}-\mathrm{j}$ & $102.00 \mathrm{~d}-\mathrm{h}$ & 101.00de \\
\hline V3B0(Dena;Control) & $94.00 \mathrm{i}-1$ & $94.00 \mathrm{i}-1$ & $94.00 \mathrm{~g}-\mathrm{i}$ \\
\hline V3B1(Dena;Blotong) & $101.00 \mathrm{e}-\mathrm{i}$ & $105.67 \mathrm{c}-\mathrm{e}$ & $103.33 \mathrm{~cd}$ \\
\hline V3B2(Dena; POEFBC) & $103.33 \mathrm{~d}-\mathrm{g}$ & $94.00 \mathrm{i}-1$ & $98.64 \mathrm{e}-\mathrm{g}$ \\
\hline V4B0(Kaba;Control) & $101.00 \mathrm{e}-\mathrm{i}$ & $112.67 \mathrm{ab}$ & $106.83 b c$ \\
\hline V4B1(Kaba;Blotong) & $108.00 b-d$ & $103.33 \mathrm{~d}-\mathrm{g}$ & $105.67 \mathrm{bc}$ \\
\hline V4B2(Kaba; POEFBC) & $108.00 b-d$ & $103.33 \mathrm{~d}-\mathrm{g}$ & $105.67 b c$ \\
\hline V5B0(Gema;Control) & $84.00 \mathrm{~m}$ & $91.00 \mathrm{kl}$ & $87.50 \mathrm{j}$ \\
\hline V5B1(Gema:Blotong) & $88.671 \mathrm{~m}$ & $91.00 \mathrm{kl}$ & $89.83 i j$ \\
\hline V5B2(Gema: POEFBC) & $93.33 \mathrm{j}-1$ & $88.671 \mathrm{~m}$ & $91.00 \mathrm{~h}-\mathrm{j}$ \\
\hline V6B0(Grobogan;Control) & $84.00 \mathrm{~m}$ & $91.00 \mathrm{kl}$ & $87.50 \mathrm{j}$ \\
\hline V6B1(Grobogan;Blotong) & $88.671 \mathrm{~m}$ & $91.00 \mathrm{kl}$ & $89.83 \mathrm{ij}$ \\
\hline V6B2(Grobogan: POEFBC) & $93.33 \mathrm{j}-1$ & $88.671 \mathrm{~m}$ & $91.00 \mathrm{~h}-\mathrm{j}$ \\
\hline V7B0(Wilis;Control) & $105.00 \mathrm{c}-\mathrm{f}$ & $107.33 b-d$ & $106.17 \mathrm{bc}$ \\
\hline V7B1(Wilis;Blotong) & $109.67 a-c$ & $105.00 \mathrm{c}-\mathrm{f}$ & $107.33 b$ \\
\hline V7B2(Wilis; POEFBC) & $112 \mathrm{ab}$ & $114.33 \mathrm{a}$ & $113.17 \mathrm{a}$ \\
\hline Average & 97.87 & 98.54 & 98.21 \\
\hline
\end{tabular}

Note: The numbers followed by the same letter on the same row or column is not different significant according to Duncan Multiple Range Test at 5\% level

Table 4. Nutrient Uptake of Multiple Plant Several Varieties with Soybean Treatment of P-Fertilizer and Addition of Organic Material

\begin{tabular}{|c|c|c|c|}
\hline \multirow[b]{2}{*}{ Treatment } & \multicolumn{2}{|c|}{ Fertilizer } & \multirow[b]{2}{*}{ Average } \\
\hline & $\begin{array}{c}\text { P0 } \\
\text { Control }\end{array}$ & $\begin{array}{c}\mathrm{P} 1 \\
\text { Fertilizer P }\end{array}$ & \\
\hline Variety & \multicolumn{2}{|c|}{.........mg ......... } & \\
\hline V1(Argomulyo) & $3.52 \mathrm{~b}$ & $2.82 \mathrm{~d}$ & $3.17 \mathrm{~b}$ \\
\hline V2(Dering) & $4.63 \mathrm{a}$ & $2.59 \mathrm{de}$ & $3.61 \mathrm{a}$ \\
\hline V3(Dena) & $2.09 \mathrm{fg}$ & 2.56de & $2.32 \mathrm{~d}$ \\
\hline V4(Kaba) & $3.26 \mathrm{c}$ & $2.09 \mathrm{fg}$ & $2.68 \mathrm{c}$ \\
\hline V5(Gema) & $1.82 \mathrm{gh}$ & $2.42 \mathrm{e}$ & $2.12 \mathrm{e}$ \\
\hline V6(Grobogan) & $2.58 \mathrm{de}$ & $4.73 \mathrm{a}$ & $3.65 \mathrm{a}$ \\
\hline V7(Wilis) & $2.11 \mathrm{f}$ & $1.61 \mathrm{~h}$ & $1.86 f$ \\
\hline \multicolumn{4}{|l|}{ Organic Matter } \\
\hline B0(Control) & $2.67 \mathrm{c}$ & $2.51 \mathrm{~d}$ & $2.59 \mathrm{~b}$ \\
\hline B1(Blotong) & $3.23 \mathrm{a}$ & $2.84 \mathrm{~b}$ & $3.03 \mathrm{a}$ \\
\hline B2(POEFBC) & $2.67 \mathrm{~cd}$ & $2.72 b c$ & $2.70 \mathrm{~b}$ \\
\hline Interaction $\mathrm{VxPxB}$ & & & \\
\hline
\end{tabular}




\begin{tabular}{lccc} 
V1B0(Argomulyo;Control) & $5.03 \mathrm{bc}$ & $3.60 \mathrm{ef}$ & $4.32 \mathrm{~b}$ \\
V1B1(Argomulyo;Blotong) & $3.04 \mathrm{ghij}$ & $1.76 \mathrm{mno}$ & $2.40 \mathrm{efg}$ \\
V1B2(Argomulyo; POEFBC) & $2.50 \mathrm{kl}$ & $3.10 \mathrm{ghi}$ & $2.80 \mathrm{~d}$ \\
V2B0(Dering;Control) & $1.49 \mathrm{op}$ & $2.67 \mathrm{hijk}$ & $2.08 \mathrm{ghi}$ \\
V2B1(Dering;Blotong) & $5.16 \mathrm{~b}$ & $2.61 \mathrm{jkl}$ & $3.89 \mathrm{c}$ \\
V2B2(Dering; POEFBC) & $7.24 \mathrm{a}$ & $2.48 \mathrm{kl}$ & $4.86 \mathrm{a}$ \\
V3B0(Dena;Control) & $3.07 \mathrm{ghij}$ & $1.52 \mathrm{op}$ & $2.30 \mathrm{fgh}$ \\
V3B1(Dena;Blotong) & $1.58 \mathrm{op}$ & $3.71 \mathrm{e}$ & $2.65 \mathrm{de}$ \\
V3B2(Dena; POEFBC) & $1.61 \mathrm{nop}$ & $2.45 \mathrm{kl}$ & $2.03 \mathrm{hij}$ \\
V4B0(Kaba;Control) & $1.59 \mathrm{op}$ & $0.48 \mathrm{r}$ & 1.031 \\
V4B1(Kaba;Blotong) & $5.17 \mathrm{~b}$ & $4.66 \mathrm{~cd}$ & $4.92 \mathrm{a}$ \\
V4B2(Kaba; POEFBC) & $3.02 \mathrm{ghij}$ & $1.14 \mathrm{pq}$ & $2.08 \mathrm{ghi}$ \\
V5B0(Gema;Control) & $1.61 \mathrm{nop}$ & $3.13 \mathrm{fgh}$ & $2.37 \mathrm{efg}$ \\
V5B1(Gema:Blotong) & $1.53 \mathrm{op}$ & $1.40 \mathrm{op}$ & $1.47 \mathrm{k}$ \\
V5B2(Gema: POEFBC) & $2.33 \mathrm{kl}$ & $2.74 \mathrm{hijk}$ & $2.53 \mathrm{def}$ \\
V6B0(Grobogan;Control) & $3.76 \mathrm{e}$ & $4.63 \mathrm{~cd}$ & $4.19 \mathrm{bc}$ \\
V6B1(Grobogan;Blotong) & $2.65 \mathrm{ijk}$ & $5.22 \mathrm{~b}$ & $3.93 \mathrm{c}$ \\
V6B2(Grobogan: POEFBC) & $1.33 \mathrm{op}$ & $4.35 \mathrm{~d}$ & $2.84 \mathrm{~d}$ \\
V7B0(Wilis;Control) & $2.161 \mathrm{~m}$ & $1.56 \mathrm{op}$ & $1.86 \mathrm{ij}$ \\
V7B1(Wilis;Blotong) & $3.50 \mathrm{efg}$ & $0.50 \mathrm{r}$ & $2.00 \mathrm{hij}$ \\
V7B2(Wilis; POEFBC) & $0.67 \mathrm{gr}$ & $2.77 \mathrm{hijk}$ & $1.72 \mathrm{jk}$ \\
\hline Average & $2.86 \mathrm{a}$ & $2.69 \mathrm{~b}$ & 2.77 \\
\hline N0: The & & & $\mathrm{cos}$ \\
\hline
\end{tabular}

Note: The numbers followed by the same letter on the same row or column is not different significant according to Duncan Multiple Range Test at 5\% level

The highest P levels were obtained at the treatment of V7P1 (0.43) and the lowest at V1P0 (0.33) (Table 4.). The results indicate that administration of $\mathrm{P}$ will cause increased solubility of soil P. Provision of $\mathrm{P}$ on each variety will give rise to unequal responses. The results showed that the varieties of Wilis had the highest $\mathrm{P}$ levels. Varieties based on efficiency against $\mathrm{P}$ can be grouped over efficient or inefficient plants. Wilis from the angle of $\mathrm{P}$ levels high but has a small seed. These results indicate that Wilis as an inefficient plant is different from Argomulyo even though his $\mathrm{P}$ levels are low but have large seeds.

The treatment of $\mathrm{P}$ fertilizer and organic matter on some soybean varieties resulted in significant differences in the $\mathrm{P}$ uptake parameter (Table 4). Characteristics of the type of plant affect the response to the application of fertilizer P. There are four varieties (Argomulyo, Dering, Kaba, and Wilis) have decreased P uptake in line with the application of P. In contrast to the varieties (Dena, Gema, and Grobogan) addition of P fertilizer.

The results also showed that the application of $\mathrm{P}$ fertilizer on soil given organic matter to seven soybean varieties decreased P uptake (Table 4). The decrease in P uptake with the addition of P fertilizer is thought to be caused by inhibition of $\mathrm{P}$ uptake by plant roots. Observations on the soil experiments showed that soybean had been watersaturated during the period of its life. Water saturated conditions will cause the plant to lack oxygen that inhibits root respiration and eventually root growth. Roots that do not have good root proliferation will inhibit P. uptake. Inhibition of nutrient uptake depending on the environment is also found (Heckman, 2007).

Application of fertilizers without regard to sustainable nutrient management will cause damage to land and water (Daniel et al., 1998; Sims et al., 1998). Some research results in New Jersey indicate that large amounts of soils have experienced excess levels of P. Based on samples collected in 2004 from commercial farmers' fields, received at the Testing Laboratory, $39 \%$ of the soil samples have $\mathrm{P}$ with a very high range (above optimum). The fertilization of $\mathrm{P}$ will increase its absorption. The diversity of plants in an area of cultivation is the reason why nutrient uptake occurs in multiple cropping cultivation system (Hanum et al., 2016).

Among plant species with each other there is a difference in the ability of nutrient uptake, between different types of differences can occur in the absorption of $\mathrm{P}$ produced as a result of genotype difference. The absorption of $\mathrm{P}$ on the 
condition without fertilizer is higher than the absorption given fertilization. This suggests that the ability of plant absorption under low $\mathrm{P}$ conditions is a mechanism that determines tolerance at low $\mathrm{P}$ in the field (Prawiranata et al., 1988). The results of this study are in line which found that the tolerance of the local varieties rice genotype was based on the ability to extract soil-bound $\mathrm{P}$, as well as the tolerant properties controlled by a loci of the principal quantitative properties which can be inherited through the cross (Wissuwa et al., 2005).

\subsection{Weight of 100 Dry Seeds (g)}

The result of $F$ test showed that the treatment of varieties had significant effect on the weight of 100 dry beans while the other treatments were organic matter, interaction of varieties with organic matter, phosphate, interaction of varieties with phosphate, phosphate interaction with organic matter, interaction of varieties, phosphate, and organic matter showed the difference is not real with the weight parameter of 100 dry beans.

The highest weight of 100 dried beans was obtained in Grobogan (V6), Dena (V3), Argomulyo (V1) varieties while the lowest was in the Gema (V5), Kaba (V4), Wilis (V7) and Dering (V2). Although statistically not significant effect, but the provision of organic material blotong (B1), resulting in the weight of 100 dry seeds highest. And the lowest with no organic matter (B0). The addition of $\mathrm{P}$ fertilizer on the combination of varietal treatment with the provision of inorganic substances was not statistically significant.

Table 5. Weight of 100 Dry Seeds Several Soybean Varieties with Fertilizer P Treatment and Addition of Organic Material

\begin{tabular}{|c|c|c|c|}
\hline \multirow[b]{2}{*}{ Treatment } & \multicolumn{2}{|c|}{ Fertilizer } & \multirow[b]{2}{*}{ Average } \\
\hline & $\begin{array}{c}\text { P0 } \\
\text { Control }\end{array}$ & $\begin{array}{c}\mathrm{P} 1 \\
\text { Fertilizer } \mathrm{P}\end{array}$ & \\
\hline \multicolumn{4}{|l|}{ Variety } \\
\hline V1(Argomulyo) & 15.65 & 16.88 & $16.27 \mathrm{a}$ \\
\hline V2(Dering) & 11.56 & 11.55 & $11.56 b$ \\
\hline V3(Dena) & 16.52 & 17.22 & $16.87 \mathrm{a}$ \\
\hline V4(Kaba) & 12.51 & 11.27 & $11.89 \mathrm{~b}$ \\
\hline V5(Gema) & 14.07 & 12.57 & $13.32 b$ \\
\hline V6(Grobogan) & 17.37 & 19.01 & $18.19 \mathrm{a}$ \\
\hline V7(Wilis) & 12.19 & 11.04 & $11.62 b$ \\
\hline \multicolumn{4}{|l|}{ Organic Matter } \\
\hline B0(Control) & 14.15 & 13.76 & 13.95 \\
\hline B1(Blotong) & 13.78 & 15.49 & 14.64 \\
\hline B2(POEFBC) & 14.87 & 13.42 & 14.15 \\
\hline \multicolumn{4}{|l|}{ Interaction $\mathrm{VxPxB}$} \\
\hline V1B0(Argomulyo;Control) & 15.31 & 18.95 & 17.13 \\
\hline V1B1(Argomulyo;Blotong) & 16.31 & 19.10 & 17.71 \\
\hline V1B2(Argomulyo; POEFBC) & 15.34 & 12.59 & 13.96 \\
\hline V2B0(Dering;Control) & 10.42 & 10.82 & 10.62 \\
\hline V2B1(Dering;Blotong) & 12.05 & 11.16 & 11.60 \\
\hline V2B2(Dering; POEFBC) & 12.23 & 12.67 & 12.45 \\
\hline V3B0(Dena;Control) & 16.05 & 16.72 & 16.39 \\
\hline V3B1(Dena;Blotong) & 16.81 & 18.08 & 17.44 \\
\hline V3B2(Dena; POEFBC) & 16.70 & 16.85 & 16.77 \\
\hline V4B0(Kaba;Control) & 12.38 & 11.65 & 12.02 \\
\hline V4B1(Kaba;Blotong) & 11.78 & 12.06 & 11.92 \\
\hline V4B2(Kaba; POEFBC) & 13.38 & 10.11 & 11.74 \\
\hline V5B0(Gema;Control) & 11.56 & 11.75 & 11.65 \\
\hline V5B1(Gema:Blotong) & 14.46 & 14.12 & 14.29 \\
\hline
\end{tabular}




\begin{tabular}{lccc} 
V5B2(Gema: POEFBC) & 16.18 & 11.85 & 14.02 \\
V6B0(Grobogan;Control) & 21.16 & 15.92 & 18.54 \\
V6B1(Grobogan;Blotong) & 12.82 & 22.25 & 17.53 \\
V6B2(Grobogan: POEFBC) & 18.12 & 18.88 & 18.50 \\
V7B0(Wilis;Control) & 12.15 & 10.48 & 11.32 \\
V7B1(Wilis;Blotong) & 12.26 & 11.64 & 11.95 \\
V7B2(Wilis; POEFBC) & 12.16 & 11.00 & 11.58 \\
\hline \multicolumn{1}{c}{ Average } & 14.27 & 14.22 & 14.24 \\
\hline
\end{tabular}

Note : The numbers followed by the same letter on the same row or column is not different significant according to Duncan Multiple Range Test at 5\% level

Treatment of varieties significantly affected the weight parameter of 100 dry seeds. The 100 -item weight was used to determine the size of soybean seeds. The size of the soybean seeds is grouped into three size groups: small seeds (6-12 g), medium- 12-14 g), and large seeds (more than $14 \mathrm{~g}$ ). Based on that, the three varieties tested are varieties with medium-sized seed criteria (Pitojo, 2003).

The average weight of 100 seeds of Argomulyo varieties can reach 19-20 g. The weight of 100 grains of dry beans is very closely related to the results achieved. If the weight of 100 seeds is higher then the greater the productivity of the results obtained. Increased production can be achieved through increased weight of 100 seeds or seed size. Seed size can also be controlled by the size of the fruit or pod. Small pods produce small seeds due to pod wall limitations, resulting in fewer cells and smaller cell sizes (Gardner et al., 1991). The weight of dry beans is influenced by the factors in the plant itself i.e., genetic factors and environmental factors. There is often a marked difference in seed size between varieties in the same plant in circumstances where both the number and size of the seeds result in variation in seed yield (Goldsworthy, 1996).

Large seed size gives a high yield of dry beans. The filling of seeds is derived from photosynthetic produced after flowering and re-translocation of stored photosynthetic (Goldsworthy, 1996). Furthermore throughout the period of reproductive growth of the annual crops that produce seeds make the seeds as the dominant utilization organs (as storage reserve and breeding). Therefore, during the filling of newly formed or stored photosynthetic seeds can be used to increase seed weight (Gardner, 1991).. The better the vegetative growth of soybean crop then the process of photosynthesis will run well so that the resulting photosynthetic more and more. Photosynthesis results from the vegetative phase to the generative phase will be stored as food reserves in the form of carbohydrates in the form of seeds. The higher the photosynthetic the seeds will also increase (Zainal et al., 2014).

\section{CONCLUSIONS}

The seven varieties used have different characteristics of root dry weight, flowering age, harvest age, P plant uptake and 100 seed weight. Flowering age of Argomulyo, Dering and Kaba varieties are not influenced by organic matter and P fertilizer. But Dena and Grobogan are more influenced by Blotong organic material. Gema varieties of flowering age are influenced by palm oil empty fruit bunches compost and P fertilizer. The varieties of Wilis flowering age are affected without the application of $\mathrm{P}$ fertilizer and organic matter. Absorption of $\mathrm{P}$ in Argomulyo was highest in the absence of organic matter and fertilizer P. Varieties Dena and Grobogan on Blotong which was given fertilizer P. Kaba and Wilis varieties were given Blotong without fertilizer P. Varieties Gema without organic material with P. fertilizer application.

\section{REFERENCES}

Zahrah, S. 2011. Response Various Varieties of Soy (Glycine Max (L) Merril) Against Provision of Organic NPK Fertilizer. J. Teknobio. 2 (1): $65-69$.

Central Bureau of Statistics. 2015. Production of Rice and Palawija Crops in Indonesia. Downloaded from http://bps.go.id.

Gunarto, L., Taher, A. Rauf, M. Makarim, A. K. Dradjat and A. A. Suyamto. 1998. Fertilization on Rice Fields. Status, Efficiency and Posforest Management Strategy. Journal of Agricultural Research and Development XVII (4): 138 - 147.

Indriani, H. K. 2007. Soil Fertility Management. Earth Script. Semarang.

Raghothama, K. G. 1999. Phosphate Acquisition. Annual Review of Plant Physiology and Plant Molecular Biology 50: $665-693$.

Cahyono. 2007. Soybean. Various Science, Semarang. 
Darjanto and Sarifah. 1987. Basic Knowledge of Flower and Technique Biology Artificial Cross Pollination. Gramedia, Jakarta.

Adisarwanto. 2008. Tropical Soybean Cultivation. Self-Helping Spreader, Jakarta.

Leovici. 2012. Exploiting Blotong On Sugar Cane Cultivation On Dry Land. University of Gajah Mada. Yogyakarta.

Suhartina. 2005. Description of Superior Variety of Beans and Tubers. Research Institute for Beans and Tubers, Malang.

Heckman, P. 2007. Starch and It's Modification For The Food Industry. Connecticut: The Avi Publishing Company Inc. Wesport.

Daniel, Th.W., J. A. Helms, F. S. Baker, 1998, Silvicultural Principles (Indonesian Edition, translated by Dr. Ir. Djoko Marsono), Gadjah Mada University Press, Yogyakarta.

Sims, D. A. and J. A. Gamon. 1998. Relationship Between Leaf Pigment Content and Spectral Reflectance Across a Wide Range of Species, Leaf Structure and Developmental Stages. Remot Sens Environ 81: 337-354.

Hanum, C., A. Rauf, I. Nasution, A. Fazrin and A. R. Habibi. 2016. Nitrogen, Phosphor, and Potassium Level in Soil and Oil Palm Tree atvarious Composition of Plant Species Mixtures Grown. 2nd International Conference on Agricultural and Biological Sciences (ABS 2016). doi: 10.1088 / 1755-1315 / 41/1/012008.

Prawiranata, W. S. Harran and P. Tjondronegoro. 1988. Basics of Plant Physiology. Department of Botany Faculty of Agriculture IPB. Bogor. 313 p.

Wissuwa, M., G. Gamat and A. M. Ismail. 2005. Is Root Growth Under Phosphorus Deficiency Affected by Source or Sink Limitations?. Journal of Experimental Botany 56 (417): 1943-1950.

Pitojo, S. 2003. Soybean Seed. Kanisius. Yogyakarta. 84 p.

Gardner, F. P., R. B. Pearce and R. L. Mitchell. 1991. Physiology of Crop Plants. Translated by H. Susilo. University of Indonesia Press, Jakarta.

Goldsworthy, P. R. and N. M. Fisher. 1996. Tropical Tropical Plant Physiology. Translator: Tohari. Gadjah Mada University Press, Yogyakarta.

Zainal, M., A. Nugroho and N. E. Suminarti. 2014. Growth Response and Soybean Crop (Glycine max (L.) Merill) At Various Levels of Fertilization N and Poultry Cage Manure. Journal of Plant Production 2(6): 484-490. 